\title{
As Easy as Bojo's ‘Oven-ready’ Brexit Pie? The Conservative Campaign
}

Aussi facile que la tarte au Brexit 'prête à cuire' de Bojo? La campagne des

Conservateurs

\section{Alma-Pierre Bonnet}

\section{(2penEdition}

\section{Journals}

Electronic version

URL: http://journals.openedition.org/rfcb/5718

DOI: $10.4000 /$ rfcb. 5718

ISSN: 2429-4373

\section{Publisher}

CRECIB - Centre de recherche et d'études en civilisation britannique

\section{Electronic reference}

Alma-Pierre Bonnet, « As Easy as Bojo's 'Oven-ready' Brexit Pie? The Conservative Campaign », Revue Française de Civilisation Britannique [Online], XXV-3 | 2020, Online since 10 September 2020, connection on 10 September 2020. URL : http://journals.openedition.org/rfcb/5718 ; DOI : https://doi.org/ $10.4000 /$ rfcb.5718

This text was automatically generated on 10 September 2020 .

\section{cc) (†)}

Revue française de civilisation britannique est mis à disposition selon les termes de la licence Creative Commons Attribution - Pas d'Utilisation Commerciale - Pas de Modification 4.0 International. 


\title{
As Easy as Bojo's 'Oven-ready' Brexit Pie? The Conservative Campaign
}

\author{
Aussi facile que la tarte au Brexit 'prête à cuire' de Bojo? La campagne des \\ Conservateurs
}

Alma-Pierre Bonnet

\section{Introduction}

1 The 2019 general election took place in a divided country in which tension and distrust in politicians had been exacerbated by months, even years, of Brexit uncertainty. Clarity was desperately needed as the political class had failed to deliver any solution to the Brexit problem. Putting the decision back to the people seemed to be the only viable way out. The 2019 general election was then seen as extremely important. It was even dubbed "a once-in-a-lifetime election" that would "decide the future of our country for generations" ${ }^{1}$. However, because of the current political chaos, it also became one the most unpredictable elections in recent history. Would it be a Brexit election, as most commentators predicted? Or maybe a social election, with a real focus on the NHS? Some even claimed that it would be "the climate election"2.

2 In the end, it turned out to be mainly about Brexit and the early uncertainty was wiped out as the Conservatives won by a landslide. They even managed to win seats in traditional Labour strongholds. Many factors have been used to explain this sweeping victory: Brexit fatigue, a charismatic leader and an opposition in disarray. All of this was encapsulated in a highly efficient Conservative campaign.

3 This clear mandate for the Tories was not a given as the previous general election, back in 2017, had resulted in a fiasco: the party lost its majority and had to rely on the DUP's ten MPs ${ }^{3}$. The Conservative campaign was heavily criticized for blowing up what should have been an easy win $^{4}$. A new approach was therefore needed, a necessity Boris Johnson's campaign team understood perfectly. But they did not carry out a clear and comprehensive overhaul of the Conservative strategy. Quite ironically, they sought 
inspiration in what political strategist Lynton Crosby had suggested they do back in 2017:

Be clear why this election is needed. Frame it as a choice between stability and uncertainty. Demonstrate to the country that the only way to secure that stability is with a solid and united party. Convince the public that this party is the Tories. And, finally, take every opportunity to contrast with Corbyn ${ }^{5}$.

As Tom McTague puts it, they fought the 2019 election with 2017 scripts $^{6}$. However, if the script was quite similar, the Conservatives had learned the lessons from the 2017 disaster and devised a more efficient strategy.

5 First, they would use a very simple message, "Get Brexit done", and replace Theresa May's focus on change with an emphasis on stability and practical conservatism. Second, they adopted a populist approach and focused on a popular leader. Prime Minister (PM) Boris Johnson proved to be both a liability and an asset as his unpredictability would sometimes hinder his charismatic appeal. Third, they would gather a very efficient campaign team as controlling Johnson's character and making the most of it became a real challenge.

6 The campaign team surrounding Boris Johnson comprised several advisors who had worked for Johnson for quite some time. Lee Cain is the PM's director of communication and was Mr Johnson's special adviser as foreign secretary. He was mainly concerned with managing the PM's media appearances and messaging during the campaign. Other members had worked with Johnson during the Vote Leave campaign in 2016. Rob Oxley, for example, was a close aide to Johnson and is now the PM's press secretary. The most notorious spin doctor is Dominic Cummings, the PM's de facto chief of staff. He played a big role during the campaign, but in the background as the official director of politics and campaign at Conservative headquarters was Australian political strategist Isaac Levido ${ }^{7}$, who was instrumental in the unexpected election of Australian PM Scott Morrison. As Dominic Cummings deferred to the young Australian (35 years old) on campaign matters, Levido brought together a team of young talents and displayed the clarity and discipline that the 2017 campaign had lacked.

7 This paper will be organized according to this threefold strategy: a populist message (I) was delivered by a charismatic yet unpredictable leader (II) who was backed by a team of young strategists ready to bend the rules, in particular online (III).

\section{A political incantation: 'Get Brexit Done'}

8 The importance and the impact of a political slogan should never be downplayed. For example, Dominic Cummings's brainchild "Vote leave, take back control", is widely credited with the eventual success of the official campaign in favour of leaving the European Union (EU) during the Brexit referendum, Vote Leave ${ }^{8}$. According to Professor Tim Haughton "it helped to mobilize the anti-establishment support of voters who felt let down by their politicians".

9 The notion of mobilization is essential here ${ }^{10}$. The origin of the word slogan is "from the Gaelic 'sluagh-ghairm' meaning a clan's battle-cry"11. It brings people together before an important event and is one of the first elements that a campaign team needs to find. A good slogan, in the words of Florian Silnicki, a communication expert and founder of 
LaFrenchCom', needs to be "short, straightforward and accessible" as its emotional appeal represents a key asset in political communication ${ }^{12}$. during the election campaign"13. But a political slogan will also "prevent people from thinking" as Olivier Reboul put $\mathrm{it}^{14}$. A political slogan therefore shares similarities with metaphors in this hiding/ highlighting phenomenon: it brings some elements to the forefront while sidelining others ${ }^{15}$. For that matter, the 2019 Conservative slogan was a case in point. Conservatives was to focus on Brexit so as to draw a line under it and move on to other issues. Its simplicity reinforced its appeal as Tim Bale, a professor of politics at Queen Mary, University of London, remarked : "slogan obviously played a part in Johnson's victory [...] partly because it appealed to leavers but also because it appealed to some remainers who are sick to the back teeth of Brexit and want to get it over with" ${ }^{16}$.

12 The origin of the slogan might explain its success as "the effectiveness [of a slogan] depends on acceptance and use by the public" ${ }^{17}$. As the Conservatives had organized a focus group in the Northern town of Bury, the idea of the "Get Brexit Done" slogan emerged from a conversation of half a dozen Tory supporters, as one Conservative strategist recalled:

"Voters were chatting about Brexit and there was a [group] of about four to five people who started talking about 'getting it done' [...] that was all they wanted: to get Brexit out of the way, out of their lives. 'Get Brexit Done' emerged from that meeting. It was trailed at the party conference and went on to define the campaign." ${ }^{18}$

Thus, the leading principle of the Tory campaign, encapsulated in the slogan, comes from the people. This bottom-up approach seems to run counter the ideologically driven campaign of Labour. The Conservatives can therefore describe themselves as being close to the people and as literally caring about what the man in the street thinks.

"Get Brexit Done" entails an inherent opposition between the government and Parliament. The 2019 election can be seen as the climax of a showdown between a Tory government, led first by Theresa May and then Boris Johnson, which asserted that the 2016 referendum result was a clear enough mandate to implement their own idea of Brexit and the British Parliament whose members voted in majority against Brexit ${ }^{19}$. Throughout the three years leading up to Brexit, the government tried several times to bypass Parliament. It even prorogued it only to be ruled out by the Supreme Court. On the other hand, Parliament managed to have a say in the Brexit process, in particular by imposing a so-called "meaningful vote" at the end of the negotiations between the government and the EU.

By focusing on "getting Brexit done", the Conservatives clearly signalled that a landslide victory would give them carte blanche to implement the will of the people. As Boris Johnson's main backdrop on the day of the result, which bore the words "the people's government", the government would be answerable only to the people, effectively creating an opposition between the people and Parliament. Westminster would therefore be here exclusively to enforce the will of the government, making Parliament irrelevant and meaningless. 

government" 25 . This political dominance rests on two key elements: strong party discipline and a powerful and unifying leader who commands personal loyalty ${ }^{26}$. The Brexit crisis, and the way it was handled by the Tories, seems to challenge this traditional conception. Theresa May was at the head of a divided party whose MPs did not hesitate to defy the official party policy and voted down her Brexit deal. Theresa May herself was no unifying figure. During her disastrous 2017 campaign, her official slogan "Strong and Stable Leadership" was soon derided into "weak and wobbly" 27 .

Boris Johnson's campaign team would make sure their candidate would not make the same mistake and would go back to what made the Tories so politically efficient: discipline and loyalty to the leader. Dominic Cummings is believed to have masterminded the groundwork. He is credited with controversial decisions before the election, such as the prorogation of Parliament or the suspension of 21 rebel MPs, including Winston Churchill's grandson. What has been dubbed as "purge" by some seems to have paid off: 
Johnson returns to No. 10 Downing Street having cleared the House of Commons of many of its anti-Brexit protagonists and supported by a fresh crop of obedient Tory MPs who have signed up to his Brexit vision ${ }^{28}$.

Johnson's public appearance as much as possible ${ }^{37}$. This approach was vindicated when several unplanned events went wrong: certain videos went viral and could have had a damaging effect on the Conservative campaign. When presented with the picture of a young boy lying on the floor of an overcrowded hospital by a journalist, Johnson refused to look at it and took the journalist's phone away. Similarly, when confronted 
by Good Morning Britain journalists for an impromptu interview, Johnson, who was in the middle of a publicity stunt delivering milk to regular people, decided to hide in a walk-in fridge nearby. Worse, one of his closest aides, Rob Oxley swore when he saw the ITV journalists.

In order to avoid getting more bad press, the campaign team tried to control Johnson's public appearance carefully to drive home the message encapsulated in the "Get Brexit Done" slogan. To achieve this, they would capitalise on Johnson's charisma and easygoing appearance. To symbolise the fact that he would literally break the Brexit deadlock, he was photographed wearing boxing gloves emblazoned with "Get Brexit Done" in Manchester. He made his point even more explicit later in the campaign when he drove a digger with "Get Brexit Done" written on its bucket through a polystyrene wall emblazoned with the word "Gridlock".

More in tune with Johnson's traditional humorous self, he parodied the 2003 romcom Love Actually into "Vote Conservative Actually". In the three-minute video, Johnson attacks Parliament by blaming it for the current chaotic situation: "with any luck, by next year, Brexit will be 'done', if Parliament doesn't block it again". By addressing people directly (he knocks on somebody's door and silently shows his message on boards) he reinforced the government of the people versus Parliament approach that we discussed in Part I. But this kind of stunt was only the tip of the iceberg and his campaign team went much further online.

\section{Unleashing hell online: the digital campaign}

Back in 2017, Labour made the most of the digital campaign by encouraging grassroots activism through a "new politics" approach. As Emma Bell put it, digital campaigning was done "in a horizontal manner which allowed people to actively get involved in a political movement" ${ }^{38}$. With organisations such as Red Labour and Momentum, Labour gained ascendency over a weak Conservative campaign. In 2019, the Tories would take the influence of the digital campaign more seriously.

31 The campaign online was handled by two New Zealanders in their 20s, Sean Topham and Ben Guerin, at the head of a ten-strong team. Before joining the conservative team, Topham and Guerin had worked on a series of controversial campaigns, in particular when they were employed by Sir Lynton Crosby ${ }^{39}$. They also played an important role in the victorious campaign of Australian Prime Minister Scott Morrison in 2019.

Despite growing concerns over transparency and calls for more regulation on digital campaigning, the pair managed to outgun Labour and to turn social networking sites into major battlegrounds. In addition to the short videos discussed in part II (the Brexit wall and the Love Actually parody) the 2019 Conservative campaign online was threefold: they would use so-called "shit-posting", blatant dirty tricks and countless ads.

In the same way as Vote Leave managed to convince people to leave the EU, the digital campaign would focus on emotions. The "Meme machine", as the two men came to be dubbed, wanted to "unlock arousal emotions... anger, excitement, pride, fear" ${ }^{40}$, as Cummings had done a few years before.

To do so, they used so-called "shit-posting", that is "the act of throwing out huge amounts of content, most of it ironic, low-quality trolling, for the purpose of provoking an emotional reaction in less Internet-savvy viewers" ${ }^{41}$. In the same vein, they would 
flood social media with "boomer memes" which are "hastily executed and comically dubious pairings of image and text pitched to older voters" 42 . The most famous example was a picture of Jeremy Corbyn's head Photoshopped onto a man in a chicken costume.

Those "boomer memes" were designed to be simple, straightforward and amusing. That way, they managed to reach out to older voters, who are usually not as concerned as younger ones with social media. Those memes were absurd and poor in quality on purpose: the more people derided them, the more publicity they got. This was all part of a plan as one anonymous source said: "we'd make them really basic and deliberately lame because they'd get shares and lift our reach; that made our reach for the harder political messages higher"43. Along with those absurd creations, the digital campaign also resorted to dirty tricks.

The bulk of the online activities were attacks on Labour. This was facilitated by a partisan press that displayed much hostility towards Labour. Researchers at Loughborough University even found that "press hostility to Labour was more than double the levels identified during the 2017 election" 44 . The campaign online backed statements by Johnson comparing Corbyn to Stalin and did not hesitate to bend the rules to bring their message home. Two examples, among others: a fake factchecking website and a mock Labour website.

During the TV debate between Johnson and Corbyn, the Conservatives rebranded their official Twitter account as "factcheckUK" to make it look like an impartial factchecking service. The account pretended that Johnson's statements were "facts", pushed pro-Conservative material and eventually declare Johnson winner of the debate. The stunt caused an outcry ${ }^{45}$. But the deed was done.

The digital team also created a fake Labour website supposed to analyse the content of the Labour manifesto. Here again, the URL was meant to cause confusion as "Labourmanifesto.co.uk" made it look official. But they did not stop there, according to the Guardian: "The Conservatives had apparently paid for a Google advert which meant internet browsers were directed to the website when they searched for "Labour" 46 .

Last but not least, the Conservatives flooded Facebook with thousands of "misleading" adverts. As Facebook took the decision in October to refuse to ban political ads and to fact-check them, the Conservatives made the most of it. According to journalist Simon Chandler " $88 \%$ of the Facebook ads the Conservatives posted in the first four days of December were deemed misleading by Full Fact, one of the U.K.'s biggest fact-checking organisations" ${ }^{47}$. Matt Walsh, a Senior Lecturer at Cardiff University, explains that "this is part of a deliberate strategy to create noise on social media, to encourage users to share content in anger or outrage, fuelling its viral reach"48. It seems therefore that the "Meme Machine", following in Dominic Cummings's footsteps, took digital campaign to a whole other level, taking full advantage of loose - or non-existent - regulation online.

\section{Conclusion}

The 2019 conservative campaign was built around one simple idea: delivering Brexit. In a context of political fatigue, promising to finally move on seems to have hit home with most voters. The Conservatives also benefited from a poorly organised Labour opposition that was embroiled in internal struggle and marred by anti-Semitism. Other parties also failed to provide a clear alternative to Johnson's compelling message. 
However, his populist triumph might be only a short-term victory as it raised questions concerning the future and the long-term survival of the Conservative Party.

Alma-Pierre Bonnet est professeur agrégé de civilisation britannique à Sciences Po Lyon. Après avoir soutenu une thèse en civilisation britannique sur une étude comparative des discours de guerre de David Lloyd George et Winston Churchill, il est actuellement PRAG d'anglais, spécialisé en civilisation et politique britannique à l'Institut d'Etudes Politiques de Lyon (Sciences Po Lyon). Il est particulièrement intéressé par la politique britannique contemporaine et ses recherches se concentrent sur la stratégie et la communication politique.

\section{BIBLIOGRAPHY}

'EU vote: Where the cabinet and other MPs stand', BBC news, 22 June 2016 https://www.bbc.com/ news/uk-politics-eu-referendum-35616946 27 February 2020.

'Press hostility to Labour reaches new levels in 2019 election campaign' https:// www.lboro.ac.uk/news-events/news/2019/december/press-hostility-to-labour-reaches-newlevels/ Consulted 3 March 2020.

Alexandre-Collier, Agnès, Avril, Emmanuelle, Les partis politiques en Grande-Bretagne, (Paris, Armand Colin, 2013 - 288 pages).

Alexandre Collier, Agnès, 'Le nouveau populisme des Tories', 29 October 2019, The Conversation, https://theconversation.com/le-nouveau-populisme-des-tories- 125740 consulted 27 February 2020.

Alexandre-Collier, Agnès, « Euroscepticism under Margaret Thatcher and David Cameron: From Theory to Practice », Observatoire de la société britannique [En ligne], 17 | 2015, mis en ligne le 01 mai 2016, consulté le 28 février 2020. URL : http://journals.openedition.org/osb/1778; DOI : https://doi.org/10.4000/osb.1778

Bale, Tim and Webb, Paul, « The Conservatives: their Sweetest Victory? », Revue Française de Civilisation Britannique [Online], XX-3 | 2015, Online since 01 December 2015, connection on 28 February 2020. URL: http://journals.openedition.org/rfcb/480; DOI: https://doi.org/10.4000/ rfcb.480.

Beckett, Andy, 'How the Tory election machine fell apart', The Guardian, 26 June 2017 https:// www.theguardian.com/politics/2017/jun/26/tory-election-machine-fell-apart-negative-tactics consulted 25 February 2020.

Bell, Emma, 'The 2017 Labour General Election Campaign: Ushering in a 'New Politics'?', Revue Française de Civilisation Britannique [Online], XXIII-2 | 2018, Online since 14 September 2018, connection on 02 March 2020. URL: http://journals.openedition.org/rfcb/2029; DOI: https:// doi.org/10.4000/rfcb.2029.

Perrigo, Billy, 'Get Brexit Done.' The 3 Words That Helped Boris Johnson Win Britain's 2019 Election', Time, 13 December 2019 https://time.com/5749478/get-brexit-done-slogan-ukelection/ consulted 27 February 2020. 
Bonnet, Alma-Pierre, « Brexit and the myth of grandeur », Metaphor and Manipulation, International conference, Lyon, 17 May 2019 to be published in ELAD-SILDA : Études de Linguistique et d'Analyse des Discours - Studies in Linguistics and Discourse.

Bonnet, Alma-Pierre, 'Coming out of the fridge', International conference, IEP Lyon, 24 April 2020.

Chandler, Simon, 'Thousands Of Misleading Facebook Ads Help Conservatives To 'Crushing' U.K. Election Victory', Forbes, 14 December 2019 https://www.forbes.com/sites/simonchandler/ 2019/12/14/thousands-of-misleading-facebook-ads-help-conservatives-to-crushing-uk-electionvictory/ consulted 3 March 2020.

Dickson, Annabelle and others, 'We're all living in Dominic Cummings' world now', Politico, 13 December 2019 https://www.politico.eu/article/dominic-cummings-uk-electio-2019-strategyconservative-victory/ consulted 28 February 2020.

Gagnon, David, (2009). 'Un slogan, et tout devient possible’. Québec français, (153), 58-60.

Hare, Geoffrey, 'Studying political slogans as communication.' Francophonie: The French Journal of the Association for Language Learning 3 (June 1991): 24.

Haughton, Tim, 'It's the slogan, stupid: The Brexit Referendum', Birmingham University, https:// www.birmingham.ac.uk/research/perspective/eu-ref-haughton.aspx consulted 27 February 2020.

Heppell, Timothy, The Tories, from Winston Churchill to David Cameron, (London, Bloomsbury, 2014, 205 pages).

Herbert, Barry III, Politically Speaking, ed. Ofer Feldman and Christ'l De Landtsheer (Westport, CT: Praeger Publishers, 1998) 161.

Hinde, Simon, "Brexit and the media", C.N.R.S. Editions | Hermès, La Revue.

Jamet, Denis et Terry, Adeline, « Principes et fonctions de la métaphore en langue de spécialité dans un cadre cognitiviste ", ELAD-SILDA [En ligne], $\mathrm{n}^{\circ}$ La métaphore dans les discours de spécialité, publié le : 08/10/2019, URL : http://publications-prairial.fr/elad-silda/index.php? $\mathrm{id}=412$.

Kavanagh, Dennis, « Brexit, the Conservatives and the General Election 2017 », Revue Française de Civilisation Britannique [Online], XXIII-2 | 2018, Online since 14 September 2018, connection on 25 February 2020. URL: http://journals.openedition.org/rfcb/2085; DOI: https://doi.org/10.4000/ rfcb.2085

Knott, Andy, ‘Boris Johnson's flirtation with populism will have lasting consequences for the Conservative Party', The Conversation, 1 October 2019 https://theconversation.com/borisjohnsons-flirtation-with-populism-will-have-lasting-consequences-for-the-conservativeparty-124360 consulted 27 February 2020.

LaFrenchCom, 26 avril 2016 https://www.lafrenchcom.fr/actualites/slogans-politiquescommunication-souvent-maladroite/ consulted 27 February 2020.

Maguire, Patrick and Grylls, George, 'Isaac Levido and the Meme Machine', Newstatesman, 4 December 2019 https://www.newstatesman.com/politics/election-2019/2019/12/isaac-levidoand-meme-machine consulted 4 March 2020.

Mason, Rowena, 'Trump says Johnson's Brexit could rule out US trade deal', The Guardian, 1 November 2019 https://www.theguardian.com/politics/2019/oct/31/trump-says-johnson-andfarage-could-form-unstoppable-force consulted 2 March 2020. 
McTague, Tom, 'Boris Johnson Bets on a Strategy Theresa May Ignored', The Atlantic, 29 November 2019 https://www.theatlantic.com/international/archive/2019/11/britain-electionconservatives-labour-2017/602737/ consulted 25 February 2020.

Miller, Harry, 'Dominic Cummings has 'done' Brexit. Now he plans to reinvent politics', Financial Times, 16 January 2020 https://www.ft.com/content/0bf8a910-372e-11ea-a6d3-9a26f8c3cba4 consulted 27 February 2020.

Morrison, Sean, 'Key players in Boris Johnson's election campaign: From Dominic Cummings to Isaac Levido and Lee Cain', Evening Standard, 13 December 2019 https://www.standard.co.uk/ news/politics/boris-johnson-election-campaign-key-players-a4312441.html consulted 26 February 2020.

Murphy, Simon, Tories set up 'Labour manifesto' website to attack Corbyn's plans', The Guardian, 21 November 2019 https://www.theguardian.com/politics/2019/nov/21/tory-party-tweets-linkto-fake-labour-manifesto-site consulted 3 March 2020.

Nianxi, Xia, « logique et slogans en politique », Presses Universitaires de France | Diogène 2008/1 $\mathrm{n}^{\circ} 221 \mid$ pages 146 à 155.

Payne, Sebastian, 'UK election: how the Tories 'got it done", Financial Times, 22 December 2019 https://www.ft.com/content/ab3692b0-2317-11ea-92da-f0c92e957a96 consulted 27 February 2020.

Rawlinson, Kevin, 'Russia involved in leak of papers saying NHS is for sale, says Reddit', The Guardian, 7 December 2019 https://www.theguardian.com/uk-news/2019/dec/07/russiainvolved-in-leak-of-papers-saying-nhs-is-for-sale-says-reddit\#_=_ consulted 2 March 2020.

Ridge-Newman, Anthony, 'Weak and wobbly' to 'get Brexit done': 2019 and Conservative campaigns', Election analysis, http://www.electionanalysis.uk/uk-election-analysis-2019/ section-4-parties-and-the-campaign/weak-and-wobbly-to-get-brexit-done-2019-andconservative-campaigns/ consulted 28 February 2020.

Ross, Tim and Tom, McTague, Betting the House: The Inside Story of the 2017 Election (London, Biteback Publishing, 2017) p. 431.

Sabine Michelon, « The Stage-Management of the leaders' personal lives in the 2015 General Election », Revue Française de Civilisation Britannique [Online], XX-3 | 2015, Online since 01 December 2015, connection on 02 March 2020. URL: http://journals.openedition.org/rfcb/515; DOI: https://doi.org/10.4000/rfcb.515.

Shukman, David, 'General election 2019: How big an issue is climate change for voters?' BBC News, 6 November 2019 https://www.bbc.com/news/science-environment-50307304 consulted 25 February 2020.

Southern, Rosalynd, Election analysis, http://www.electionanalysis.uk/uk-election-analysis-2019/ section-6-the-digital-campaign/big-chickens-dumbfakes-squirrel-killers-was-2019-the-electionwhere-shitposing-went-mainstream/ consulted 2 March 2020.

The Conversation, 'UK election 2019: conspiracy or cock-up? The digital dirty tricks marring this campaign' 28 November 2019 https://theconversation.com/uk-election-2019-conspiracy-orcock-up-the-digital-dirty-tricks-marring-this-campaign-127847 consulted 3 March 2020.

Vote Leave, 19 April 2016 http://www.voteleavetakecontrol.org/

michael_gove_s_oped_for_bbc_radio_4_today_programme.html consulted 27 February 2020. 
Waterson, Jim, 'Tories hire Facebook propaganda pair to run online election campaign', The Guardian, 23 October 2019 https://www.theguardian.com/politics/2019/oct/23/tories-hirefacebook-propaganda-pair-to-run-online-election-campaign consulted 2 March 2020.

Waterson, Jim, 'Tories pretend to be factchecking service during leaders' debate', The Guardian, 19 November 2019 https://www.theguardian.com/politics/2019/nov/19/tories-tweet-anti-labourposts-under-factcheckuk-brand consulted 3 March 2020.

White, Jonathan, 'Everyone says this is a once-in-a-lifetime election. Is that why it's been so dirty?' The Guardian, 10 December 2019 https://www.theguardian.com/commentisfree/2019/ dec/10/once-lifetime-election-dirty-democracy consulted 25 February 2020.

YouGov, Does Britain understand Brexit? https://yougov.co.uk/topics/politics/articles-reports/ 2019/01/11/does-britain-understand-brexit consulted 28 February 2020.

\section{NOTES}

1. Jonathan White, 'Everyone says this is a once-in-a-lifetime election. Is that why it's been so dirty?'

The Guardian, 10 December 2019 https://www.theguardian.com/commentisfree/2019/dec/10/ once-lifetime-election-dirty-democracy consulted 25 February 2020.

2. David Shukman, 'General election 2019: How big an issue is climate change for voters?' BBC News, 6 November 2019 https://www.bbc.com/news/science-environment-50307304 consulted 25 February 2020.

3. Dennis Kavanagh, «Brexit, the Conservatives and the General Election 2017 », Revue Française de Civilisation Britannique [Online], XXIII-2 | 2018, Online since 14 September 2018, connection on 25 February 2020. URL: http://journals.openedition.org/rfcb/2085; DOI: https://doi.org/10.4000/ rfcb.2085

4. Andy Beckett, 'How the Tory election machine fell apart', The Guardian, 26 June 2017 https:// www.theguardian.com/politics/2017/jun/26/tory-election-machine-fell-apart-negative-tactics consulted 25 February 2020.

5. Ross, Tim and Tom, McTague, Betting the House: The Inside Story of the 2017 Election (London, Biteback Publishing, 2017) p. 431.

6. Tom McTague, 'Boris Johnson Bets on a Strategy Theresa May Ignored', The Atlantic, 29 November 2019 https://www.theatlantic.com/international/archive/2019/11/britain-electionconservatives-labour-2017/602737/ consulted 25 February 2020.

7. Sean Morrison, 'Key players in Boris Johnson's election campaign: From Dominic Cummings to Isaac Levido and Lee Cain', Evening Standard, 13 December 2019 https://www.standard.co.uk/ news/politics/boris-johnson-election-campaign-key-players-a4312441.html consulted 26 February 2020.

8. Harry Miller, 'Dominic Cummings has 'done' Brexit. Now he plans to reinvent politics', Financial Times, 16 January 2020 https://www.ft.com/content/obf8a910-372e-11eaa6d3-9a26f8c3cba4 consulted 27 February 2020.

9. Tim Haughton, 'It's the slogan, stupid: The Brexit Referendum' https:// www.birmingham.ac.uk/research/perspective/eu-ref-haughton.aspx consulted 27 February 2020.

10. Xia Nianxi, « logique et slogans en politique », Presses Universitaires de France | « Diogène » 2008/1 n²21 | pages 146 à 155.

11. Geoffrey, Hare, "Studying political slogans as communication." Francophonie: The French Journal of the Association for Language Learning 3 (June 1991): 24. 
12. LaFrenchCom, 26 avril 2016 https://www.lafrenchcom.fr/actualites/slogans-politiquescommunication-souvent-maladroite/ consulted 27 February 2020.

13. «Le slogan politique se veut la synthèse absolue du programme d'un parti au moment précis de la campagne électorale » David, Gagnon, (2009). Un slogan, et tout devient possible. Québec français, (153), 58-60.

14. Olivier, Reboul, (1975), Le slogan, (Paris, Complexe, p. 11).

15. Denis Jamet et Adeline Terry, «Principes et fonctions de la métaphore en langue de spécialité dans un cadre cognitiviste», ELAD-SILDA [En ligne], $\mathrm{n}^{\circ}$ La métaphore dans les discours de spécialité, publié le : 08/10/2019, URL : http://publications-prairial.fr/elad-silda/index.php? id $=412$.

16. Billy Perrigo, 'Get Brexit Done.' The 3 Words That Helped Boris Johnson Win Britain's 2019 Election', Time, 13 December 2019 https://time.com/5749478/get-brexit-done-slogan-ukelection/ consulted 27 February 2020.

17. Herbert, Barry III, Politically Speaking, ed. Ofer Feldman and Christ'l De Landtsheer (Westport, CT: Praeger Publishers, 1998) 161.

18. Sebastian Payne, 'UK election: how the Tories 'got it done", Financial Times, 22 December 2019 https://www.ft.com/content/ab3692b0-2317-11ea-92da-f0c92e957a96 consulted 27 February 2020.

19. More than $65 \%$ of MPs declared they would vote to remain. Source: 'EU vote: Where the cabinet and other MPs stand', BBC news, 22 June 2016 https://www.bbc.com/news/uk-politics-eureferendum-3561694627 February 2020.

20. Agnès Alexandre Collier, 'Le nouveau populisme des Tories', The Conversation, 29 October 2019 https://theconversation.com/le-nouveau-populisme-des-tories-125740 consulted 27 February 2020.

21. Encyclopædia Britannica https://www.britannica.com/topic/populism consulted 27 February 2020.

22. Andy Knott, 'Boris Johnson's flirtation with populism will have lasting consequences for the Conservative Party', The Conversation, 1 October 2019 https://theconversation.com/borisjohnsons-flirtation-with-populism-will-have-lasting-consequences-for-the-conservativeparty-124360 consulted 27 February 2020.

23. Alma-Pierre, Bonnet, "Brexit and the myth of grandeur ", Metaphor and Manipulation, International conference, Lyon, 17 May 2019 to be published in ELAD-SILDA: Études de Linguistique et d'Analyse des Discours - Studies in Linguistics and Discourse.

24. Vote Leave, 19 April 2016

http://www.voteleavetakecontrol.org/

michael_gove_s_oped_for_bbc_radio_4_today_programme.html consulted 27 February 2020.

25. Agnès, Alexandre-Collier, Emmanuelle, Avril, Les partis politiques en Grande-Bretagne, (Paris, Armand Colin, 2013 - 288 pages).

26. Timothy, Heppell, The Tories, from Winston Churchill to David Cameron, (London, Bloomsbury, 2014, 205 pages).

27. Anthony Ridge-Newman, 'Weak and wobbly' to 'get Brexit done': 2019 and Conservative campaigns', Election analysis http://www.electionanalysis.uk/uk-election-analysis-2019/ section-4-parties-and-the-campaign/weak-and-wobbly-to-get-brexit-done-2019-andconservative-campaigns/ consulted 28 February 2020.

28. Annabelle Dickson and others, 'We're all living in Dominic Cummings' world now', Politico, 13 December 2019 https://www.politico.eu/article/dominic-cummings-uk-electio-2019-strategyconservative-victory/ consulted 28 February 2020.

29. Ibid, Financial Times, 22 December 2019

30. Agnès Alexandre-Collier, " Euroscepticism under Margaret Thatcher and David Cameron : From Theory to Practice », Observatoire de la société britannique [En ligne], 17 | 2015, mis en ligne le 
01 mai 2016, consulté le 28 février 2020. URL : http://journals.openedition.org/osb/1778 ; DOI : https://doi.org/10.4000/osb.1778

31. YouGov, Does Britain understand Brexit? https://yougov.co.uk/topics/politics/articlesreports/2019/01/11/does-britain-understand-brexit consulted 28 February 2020.

32. Tim Bale and Paul Webb, "The Conservatives: their Sweetest Victory? ", Revue Française de Civilisation Britannique [Online], XX-3 | 2015, Online since 01 December 2015, connection on 28 February 2020. URL: http://journals.openedition.org/rfcb/480; DOI: https://doi.org/10.4000/ rfcb.480.

33. In addition to his two mandate as London mayor, Johnson often appeared on TV and he has also extensively written on the European Union, as a Brussels correspondent for the Daily Telegraph in the 90s, very often attacking the EU and coining popular "Euromyths". Source: Simon Hinde, Brexit and the media, C.N.R.S. Editions | « Hermès, La Revue ».

34. Sabine Michelon, «The Stage-Management of the leaders' personal lives in the 2015 General Election », Revue Française de Civilisation Britannique [Online], XX-3 | 2015, Online since 01 December 2015, connection on 02 March 2020. URL: http://journals.openedition.org/rfcb/515; DOI: https://doi.org/10.4000/rfcb.515

35. Kevin Rawlinson, 'Russia involved in leak of papers saying NHS is for sale, says Reddit', The Guardian, 7 December 2019 https://www.theguardian.com/uk-news/2019/dec/07/russiainvolved-in-leak-of-papers-saying-nhs-is-for-sale-says-reddit\#___ consulted 2 March 2020.

36. Rowena Mason, 'Trump says Johnson's Brexit could rule out US trade deal', The Guardian, 1 November 2019 https://www.theguardian.com/politics/2019/oct/31/trump-says-johnson-andfarage-could-form-unstoppable-force consulted 2 March 2020.

37. Alma-Pierre, Bonnet, "Coming out of the fridge", International conference, IEP Lyon 24 April 2020.

38. Emma Bell, « The 2017 Labour General Election Campaign: Ushering in a 'New Politics'? ", Revue Française de Civilisation Britannique [Online], XXIII-2 | 2018, Online since 14 September 2018, connection on 02 March 2020. URL: http://journals.openedition.org/rfcb/2029; DOI: https:// doi.org/10.4000/rfcb.2029

39. Jim Waterson, 'Tories hire Facebook propaganda pair to run online election campaign', The Guardian, 23 October 2019 https://www.theguardian.com/politics/2019/oct/23/tories-hirefacebook-propaganda-pair-to-run-online-election-campaign consulted 2 March 2020.

40. Ibid, Newstatesman, 4 December 2019.

41. Rosalynd, Southern, Election analysis http://www.electionanalysis.uk/uk-electionanalysis-2019/section-6-the-digital-campaign/big-chickens-dumbfakes-squirrel-killers-

was-2019-the-election-where-shitposing-went-mainstream/ consulted 2 March 2020.

42. Ibid, Newstatesman, 4 December 2019

43. Ibid, The Guardian, 23 October 2019

44. 'Press hostility to Labour reaches new levels in 2019 election campaign' Loughborough University, https://www.lboro.ac.uk/news-events/news/2019/december/press-hostility-tolabour-reaches-new-levels/ Consulted 3 March 2020.

45. Jim Waterson, 'Tories pretend to be factchecking service during leaders' debate', The Guardian, 19 November 2019 https://www.theguardian.com/politics/2019/nov/19/tories-tweetanti-labour-posts-under-factcheckuk-brand consulted 3 March 2020.

46. Simon Murphy, Tories set up 'Labour manifesto' website to attack Corbyn's plans', The Guardian, 21 November 2019 https://www.theguardian.com/politics/2019/nov/21/tory-partytweets-link-to-fake-labour-manifesto-site consulted 3 March 2020.

47. Simon Chandler, 'Thousands Of Misleading Facebook Ads Help Conservatives To 'Crushing' U.K. Election Victory', Forbes, 14 December 2019 https://www.forbes.com/sites/simonchandler/ 2019/12/14/thousands-of-misleading-facebook-ads-help-conservatives-to-crushing-uk-electionvictory/ consulted 3 March 2020. 
48. The Conversation, 'UK election 2019: conspiracy or cock-up? The digital dirty tricks marring this campaign' 28 November 2019 https://theconversation.com/uk-election-2019-conspiracy-orcock-up-the-digital-dirty-tricks-marring-this-campaign-127847 consulted 3 March 2020.

\section{ABSTRACTS}

Just two years after a disastrous campaign which cost Theresa May her majority in Parliament and annihilated her hope of delivering Brexit, the Conservative Party managed to turn things around and secure a landslide victory. However surprising the result might have been, many factors can actually be used to explain this political success: a weak and disorganized opposition that failed to provide any clear solutions to the political gridlock, a general feeling of Brexit weariness and, of course, an efficient Conservative campaign. This paper will analyse the Conservative campaign to understand how the Tories managed to easily win an election that was considered by many as extremely important and whose result was almost impossible to predict. First, we will deal with the official slogan of the Conservative campaign: "Get Brexit Done". We will then see that everything was organized around this simple message: making the most of the popularity of a highly unstable candidate, Boris Johnson, and using any means possible online to drive the point home.

Seulement deux ans après une campagne désastreuse qui a couté à Theresa May sa majorité parlementaire et détruit ses chances de mener à bien le Brexit, le Parti conservateur a réussi à retourner la situation et a obtenu un raz-de-marée électoral. Bien que surprenant, ce succès peut être expliqué : une opposition faible et désorganisée qui n'a pas su trouver de solution à l'impasse politique, un sentiment de lassitude envers le Brexit et bien sûr une campagne conservatrice qui a fait mouche. Cet article analyse la campagne conservatrice de 2019 pour comprendre comment les Tories ont réussi à remporter une élection qui était vue par beaucoup comme capitale mais aussi impossible à prédire. Dans un premier temps nous traiterons du slogan officiel « Get Brexit Done ». Nous verrons alors que toute la campagne s'articulait autour de ce message très simple : il fallait capitaliser sur la popularité de Boris Johnson, tout en contrôlant son côté imprévisible, et utiliser tous les moyens possibles pour faire passer le message sur le Brexit.

\section{INDEX}

Mots-clés: Brexit, Parti conservateur, Boris Johnson, Dominic Cummings

Keywords: Brexit, Conservative Party, Boris Johnson, Dominic Cummings

\section{AUTHOR}

\section{ALMA-PIERRE BONNET}

Sciences Po Lyon. 